\title{
Współczesny polski dyskurs publiczny w perspektywie międzynarodowej. Fragment dyskusji
}

\author{
Public Discourse in International Perspective. Round Table \\ Discussion
}

\section{Style dyskursu}

Stanisław Gajda: Jak toczy się / jest prowadzony polski dyskurs publiczny? Zarówno ten wewnątrzpolski, jak i w skali międzynarodowej? Czy można przyjąć tezę o rozpadzie przestrzeni publicznej i jej prywatyzacji oraz destrukcji komunikacyjnego rozumu jako rezultatu bezładu moralnego i prawnego, politycznej niekompetencji, mentalnej bezsiły itd.? Czy w konsekwencji jesteśmy skazani na formy dyskursu i języka właściwe sferze prywatnej, na języki autorytarne, nowomowne, fundamentalistyczne? Dlaczego nie funkcjonują mechanizmy pozwalające eliminować „nieuczciwość” i demagogię?

Co z mityczną polską tolerancją i pluralizmem? Czy Polacy godzą się z jednoczesną przynależnością jednostek do wielu społecznych całości - wspólnot wielkich (np. europejskiej, narodowej) i mniejszych (np. instytucjonalnych, lokalnych)? Czy zatem nie odejść od utopii dobra wspólnego na rzecz realności konfliktów, od idealnego społeczeństwa obywatelskiego na rzecz realnego społeczeństwa, w którym podstawą działania są realne interesy? Dlaczego nie umiemy radzić sobie z nieuniknionymi konfliktami?

Jerzy Mikułowski Pomorski: Sądzę, że taka pierwszą oznaką było wprowadzenie języków i terminologii, które miały swoje znaczenia ,podkulturowe”. Pamiętam, zaraz po odzyskaniu niepodległości pewne osoby, które współpracowały z rządem stanu wojennego, były nazywane kolaborantami, co rozumiano dotychczas jako 'kolaboranci z hitlerowcami'. Obawiam się, że dziś występuje w dyskursie publicznym bardzo wiele takich politycznych wejść posługujących się swoim subkulturowym językiem, który się wytwarza na zasadzie: spróbuję uruchomić albo wynaleźć zjadliwą metaforę i użyć jej w jakimś dyskursie publicznie dostępnym. A to po to, by raczej zaciemnić dyskurs, niż go rozjaśnić. Są to różne próby puszczania w obieg bon motów, powiedzeń, symboli, które uruchamiają ludzie wtedy, 
gdy przygotowują się do powodowania semantycznego zamieszania (tego, co młodzież nazywa ściema). Jest tam rozwinięta metaforyka, są aluzje historyczne, z czego powstają trudne do rozpoznania zbitki. Dziennikarze, jeżeli uczestniczą w dyskursie publicznym, powinni te zbitki wyczyścić, to znaczy wyjaśnić ich rozumienie do końca. Muszę powiedzieć, że dziennikarze poświęcają temu sporo uwagi - trzeba ich za to pochwalić.

Poważnym problemem jest dopuszczanie do całkowitej niekomunikatywności dyskursu. Bowiem bardzo często w miarę rozpędu, jaki nabiera wymiana zdań - dyskusja przyjmuje formę magla. Gdy wszyscy mówią, powstaje polifonia nie słów, ale wręcz chrząknięć, pisków, treli, buczeń, skrzypień, jak też i nakładających się głosów. Z takiego wielogłosu tylko nieliczni, jak Donizetti, wydobywają cudowne brzmienia, jak w oktecie w Łucji z Lammermooru. Nie potrafią tego jednak realizatorzy telewizyjni. W efekcie mamy do czynienia z „zamulaniem”, krzykiem lub inną formą ekspresji. Słowo traci, ustępuje, staje się czymś w rodzaju dodatku, okazją do wydawania różnych dźwięków. To z pewnością nie jest dyskurs europejski. Nie wiem jednak, jaki.

Jerzy Bralczyk: Proszę państwa, wydaje się, że to, o czym mówił Pan Profesor Mikułowski Pomorski, jest bardzo ważne. To usłowienie i jego atrakcyjność. Dość często ta atrakcyjność łączy się z wizją niezwykle uproszczoną. Przykładowo moherowe berety, które w pogardliwy sposób identyfikowały pewną istotną grupę ludzi. Wydaje się, że można mówić o kilku przynajmniej takich wzorcach językowych, które dla użytkowników, zwłaszcza młodych, mogą się jawić jako atrakcyjne.

Atrakcyjnym wzorcem będzie na przykład wzorzec prezentowany przez język PR-u i reklamy. Ciekaw jestem, czy będzie tutaj też mowa o zarządzaniu dyskursem publicznym. Chętnie bym usłyszał takie właśnie sformułowanie. Usiłujemy zarządzać tym dyskursem. Na szczęście nam się to nie udaje. Można zarządzać różnymi zjawiskami społecznymi.

Atrakcyjny może być wzorzec zideologizowany, np. ten, który ma charakter narodowo-katolicko-konserwatywny i który zdominował politykę na jakiś czas. Nawet jeśli ktoś krytykuje ten typ postrzegania, czy też wysławiania świata, to też jakoś do tej dawnej romantycznej, sienkiewiczowsko-konopnickiej mowy próbuje się odwoływać.

Atrakcyjny bywa dyskurs eurożargonowy. Jednak jest on dosyć trudny i jeśli się nawet pojawia, to wymaga od użytkowników pewnej wiedzy. Odwołuje się on do oświeceniowych ideałów.

Atrakcyjny jest wzorzec populistyczny, który - upraszczając rzeczywistość - może wyraziście pokazać to, co jest najistotniejsze. Obejrzałem niedawno film Stanisława Tyma 
Ryś. Jest tam charakterystyczne przemówienie posła mniejszości litewskiej, granego przez Stanisława Tyma. Przemówienie najpierw do nikogo, a potem, jak się okazało, do wszystkich. Mówca operował pojęciami, z którymi każdy łatwo się utożsamia. Porwał salę, nie bardzo sam wiedząc, co mówi.

Teraz pytanie - co z tego może pozostać dłużej? Pewnie, jak uczą nas historycy idei, te wzorce, mając oparcie w jakichś ideologicznych klasyfikacjach oraz w wyborach pewnego sposobu postrzegania świata, mogą długo jeszcze istnieć. Pani Profesor użyła określenia Himalaje hipokryzji. Spodobało mi się ono dlatego, że posiada dwa ,hi”. Stosowanie wymienionych wyżej wzorców ma charakter jawnej gry. Wybiera się je, choć bez przekonania. Dyskurs publiczny w znacznej mierze jest grą. I jeśli na to spojrzymy z tej strony, to możemy oczywiście też się martwić, bo lubimy wszystko, co jest naprawdę. No ale dobrze, że nie zawładnął dyskursem publicznym fanatyzm.

Wiesław Przyczyna: Chciałbym w tym miejscu podzielić się z państwem moimi uwagami na temat języka dyskursu kościelnego. Kościół w Polsce posługuje się dziś często językiem dominacji. Skąd to się bierze? Stąd, że niektórzy jego urzędowi przedstawiciele są przekonani, iż posiedli całą prawdę. W ślad za takim przekonaniem idzie nierzadko myśl, że kto ma prawdę, ten ma władzę. Jeżeli mam władzę, to próbuję tę prawdę narzucić innym, nie licząc się z tym, że inni mogą mieć własne zdanie. Nikt nie ma patentu na prawdę. Ta prawda jest nam przez Pana Boga uchylana. Wszyscy jesteśmy w drodze do niej. Chrystus mówi „Ja jestem drogą, prawdą i życiem”, mówi o metaforze drogi, która prowadzi do prawdy. Owa wielość dróg musi być przez Kościół uznana i respektowana. Inaczej mówiąc, Kościół powinien nauczyć się słuchać, także tych, którzy mają odmienne zdanie.

Inną tendencją widoczną $\mathrm{w}$ dyskursie publicznym Kościoła jest skłonność do nadmiernych uproszczeń. Odnosi się to zwłaszcza do tworzenia obrazu osoby na podstawie grupy, do której ona należy, a o której to grupie mamy swoje prywatne zdanie. Osobę „opisuje się” wówczas niejako automatycznie, na podstawie przynależności. Cechy grupy przerzucane są na tę osobę, a giną wszystkie jej cechy indywidualne. Jeżeli powie się: on jest $z$ „,Tygodnika Powszechnego”, to już nie trzeba nic więcej dodawać, bo wiadomo liberat, filosemita, trzymajacy z inaczej myślacymi. Podobnie, gdy powiemy: on jest z Radia Maryja, też natychmiast „wiemy”: konserwatysta, ciemnogród, moherowe berety. Owa kategoryzacja, która tak zubaża widzenie, jest niegodna Ewangelii i bardzo utrudnia jakąkolwiek komunikację miedzy ludźmi, bowiem sprowadza ich do bardzo funkcjonalnego przedmiotu. 
I jeszcze jedna cecha, która charakteryzuje ten dyskurs, to podział na „my” i „oni”. „My” tworzymy wspólnotę w oparciu o pewne wartości i wobec wspólnego przeciwnika. „My” jesteśmy dobrzy, my mamy dobre chęci, a „oni” są tylko źli. Jeżeli „my” ponosimy porażki, to nie dlatego, że jesteśmy nieudolni, ale dlatego, że „oni” nam przeszkadzają. Jak twierdzi Virginia Satir, „oni” stają się rodzajem szwedzkiego stołu dla naszych negatywnych fantazji.

Wszystko, co złe, można im dowolnie przypisać, w zależności od potrzeb i okoliczności. Znaczy to, że ktoś, kto przez całe lata był przeciwko „nam”, ale od bliżej nieokreślonego momentu postanowił do „nas” dołączyć, jest, od zawsze był „nasz”, taki się urodził, a jego minione, mniej chlubne życie jest przemilczane. Ale bywa też i odwrotnie. Jeśli ktoś, kto zawsze uznawany był za porządnego człowieka, dobrego chrześcijanina, „nam” się narazi, wypowiadając nieakceptowane przez „nas” opinie na aktualne tematy, okazuje się nagle, że nigdy nie był „nasz”, że był „obcy” od zawsze.

Źródeł takiego stanu rzeczy upatrywałbym - $\mathrm{z}$ jednej strony - w próbie upolitycznienia chrześcijaństwa, a $\mathrm{z}$ drugiej - $\mathrm{W}$ próbie chrystianizacji polityki. Upolitycznienie chrześcijaństwa jest czymś niebezpiecznym, oznacza pierwszeństwo polityki nad duszpasterstwem, a w konsekwencji dążenie do jakiejś uświęconej demokracji. Natomiast chrystianizacja polityki oznacza dążenie do ograniczenia samowoli państwa, wyniesienia duszpasterstwa ponad politykę, ale bez przekreślania autonomii sfery politycznej. To jest spór, który idzie przez wieki i trwa po dziś dzień.

Andrzej Zoll: Zastanawiam się nad przyczyną posługiwania się tego typu stylistyką w dyskursie publicznym, szczególnie jeżeli chodzi o politykę. Myślę, że w dużej mierze jest to wynikiem niechęci albo niemożliwości używania argumentów merytorycznych, i dlatego przechodzi się na emocjonalne niszczenie drugiej strony. Mam tutaj pewne doświadczenie przez kilkanaście lat bardzo blisko obserwowałem polityków, nigdy nie będąc politykiem. I w każdej ekipie można było spotkać tego typu argumentację. Projekt złożony przez inną grupę polityczną jest zasadny, ale nie jest nasz, wobec czego my go nie możemy przyjąć. W takiej dyskusji nie można oczywiście używać argumentów merytorycznych, bo podziela się argumenty drugiej strony. Ale trzeba drugą stronę zniszczyć. Wobec tego musimy ich ośmieszyć, używając takich czy innych chwytów, które będą w opinii publicznej dyskwalifikowały przeciwnika politycznego. To jest wielka słabość polskiego życia politycznego, ta niemożność zaakceptowania czegoś, co wychodzi z innego obozu. 
Walery Pisarek: Nawet z tego samego, co sami uznalibyśmy za dobre. Skoro jednak to wyszło z drugiego obozu, należy to zohydzić.

Chcę w tym module zwrócić uwagę na to, jak media nadają znaczenie poszczególnym nazwom i kształtują stereotypowe wyobrażenia ludzi, ich zachowań, przedmiotów i wydarzeń. Znaczenia, może w mniejszym stopniu rzeczowe, przedmiotowe, a raczej znaczenia konotatywne, emotywne, skojarzenia, które się budzą przy kontakcie najpierw z danym człowiekiem czy z przedmiotem, który został jakoś nazwany, a potem z samym jego imieniem, nazwiskiem, nazwą. Dużo się pokazuje ostatnio złych lekarzy i pielęgniarek oraz sporo pisze o nich; zapewne nie tylko ja się przyłapuję na tym, ale także - jak sądzę - wielu Polaków, że lekarz to ktoś moralnie podejrzany. Mój lekarz rodzinny wyznał mi niedawno: „Czasem wstyd mi się dziś przyznawać, że jestem lekarzem, bo każdy na mnie zaraz patrzy jak na łapownika albo niemal mordercę". To samo dotyczy zresztą także i księży w niektórych środowiskach, a także - co chyba ze względów społecznych najgorsze nauczycieli. Starszy dyrektor gimnazjum? - O, ten to na pewno molestuje swoje uczennice! Zarażani jesteśmy w ten sposób wszyscy przez media.

Sytuacja nie jest tak tragiczna, jak mogłaby być, dzięki innej, też zresztą ujemnej cesze mediów. A mianowicie dzięki temu, że dzisiaj głównym ich celem jest przyciągnięcie czytelnika, słuchacza czy widza - i wobec tego muszą ciągle czymś nowym i ciekawym, czymś pasjonującym (co dawniej nazywano rewolwerowym, a od pewnego czasu - a cóż to jest rewolwer! - nazywa bombowym) przynęcać nowych odbiorców. Wątki są ciągle nowe a więc jak się skończą lekarze, nauczyciele i księża, przyjdzie kolej na następne zawody. Mamy ich dużo, a potem jeszcze mogą dojść mieszkańcy poszczególnych regionów, miast i miasteczek - ho ho, wystarczy tematów do końca świata dla zdolnych dziennikarzy, dla mediów zdolnych i dbałych o swoją publiczność.

Ze względu na to, że większość „,sensacyjnych” newsów żyje w naszych mediach nie dłużej niż jeden dzień, nie jest to takie groźne, ale na pewne stare mechanizmy chciałbym zwrócić uwagę. Często się mówi, powszechnie piętnuje i wytyka, że w języku naszym i w języku naszych sąsiadów, przyjaciół i przeciwników występuje tak wiele metafor ze świata wojny. Niemal wszyscy walcza czy walczyli o coś, prowadzimy wojny na różnych frontach, mówimy o atakach, ofensywach, działach, okopach i bombach, poruszając sprawy najodleglejsze od spraw wojny. Tymczasem, moim zdaniem, ta militaryzacja języka nie jest tak groźna, jak odmilitaryzowanie rzeczywistych zachowań militarnych, rzeczywistych elementów wojny i wojennego rzemiosła. Temu celowi służy pomniejszanie, swego rodzaju oswajanie zjawisk groźnych. Jak wiadomo, pierwsza bomba atomowa, która spadła na 
Hiroszimę, nazywała się Little Johnny, Mały Jaś - miło i przyjemnie. Departamenty i ministerstwa wojny zostają przemianowane na ministerstwa i departamenty obrony bynajmniej nie wtedy, kiedy się deklaruje rezygnację z prowadzenia działań wojskowych poza granicami własnego kraju. Te praktyki nazewnicze są nadal aktualne. Nadal się prowadzi misje stabilizacyjne. Do tego zbioru pojęć należy też nasza tarcza antyrakietowa. Tarcza to jest coś, co chroni coś, zasłania coś przed czymś, ale nasza tarcza to jest, o dziwo, tarcza strzelająca, szczególny typ tarczy antyrakietowej, wystrzeliwującej rakiety. Mówiąc to, nie chcę deklarować niechęci wobec planów instalacji jej w Polsce, tylko staram się uświadomić perswazyjność samej nazwy.

Podobne zjawisko występuje $\mathrm{w}$ wielu politycznie poprawnych zaleceniach osłabiania opozycji: swój-obcy. Wedle tych zaleceń powinniśmy się starać odnosić do obcych, żeby oni jak najmniej czuli, że nie są „swoi”. A to jest - moim zdaniem - dopiero niebezpieczne, kiedy nagle stwierdzamy, że nie ma wokół nas obcych, tylko jesteśmy sami swoi. I kiedy zaprzeczamy obcemu prawa do tego, żeby być obcym. Także pod względem światopoglądowym, przyjmując milcząco, że wszyscy „przyzwoici” ludzie myślą tak, jak naszym zdaniem myśleć należy. Dzisiaj wielu ludzi, zwłaszcza młodych, chce być obcymi, chce być innymi niż wszyscy, chce podkreślać - prowokacyjnie podkreślać - swoją inność i swoją obcość. Czasem może właśnie dlatego, że tej obcości się im odmawia.

Marek Zybura: Może jeszcze dopełnię, w nawiązaniu do tego, co moi przedmówcy mówili o zawłaszczaniu języka, wydawałoby się, że już w publicznym dyskursie przypisanego do pewnych elementów tegoż dyskursu, i stosowaniu go naraz z instrumentalizacyjną intencją w odniesieniu do innych elementów dyskursu. Jak wspomniał już Pan Profesor Pomorski, w Polsce media epatują słuchaczy/czytelników terminem kolaboracja - zastrzeżonym, wydawałoby się, w naszej tradycji do okresu II wojny światowej - w odniesieniu do kontekstów stanu wojennego. Z kolei w ostatnich latach w Niemczech możemy zaobserwować zjawisko, że już nie tylko populistyczne media, ale skądinąd poważni publicyści, a nawet profesorowie historii stosują terminologię wydawałoby się zastrzeżoną dotąd dla charakteryzowania polityki eksterminacyjnej III Rzeszy wobec narodów słowiańskich na Wschodzie Europy do działań aliantów wobec państwa i społeczeństwa niemieckiego podczas II wojny. Bombardowanie miast niemieckich prowadzone przez aliantów dla złamania morale hitlerowskiego społeczeństwa nazywane jest ostatnio wcale często mianem Vernichtungskrieg, gdy dotychczas terminu tego można było tylko i wyłącznie użyć w odniesieniu do tego, co wyrabiały na Wschodzie nazistowskie 
sonderkomanda. Tak więc dyskurs publiczny może być grą i w takim sensie, grą polegającą na żonglowaniu utrwalonymi potencjałami asocjacyjnymi w pożądanym politycznie czy ideologicznie kierunku.

Stanisław Gajda: Pozwólmy teraz aktywnie włączyć się do naszej debaty jej uczestnikom z sali. Proszę bardzo.

Grażyna Habrajska: Chciałam ustosunkować się do Państwa wypowiedzi. Pan Profesor Zoll mówił, że w dyskursie publicznym nie ma argumentacji merytorycznej. Nie jest to chyba specjalnie dziwne w odniesieniu do tematyki historycznej i bioetycznej. Dyskusja sprowadza się tu do problemów moralno-etycznych. Przy zagadnieniach ekonomicznych spodziewalibyśmy się właśnie takiej merytorycznej argumentacji. Ale problemy ekonomiczne mniej nas zajmują, dyskursy publiczne o sprawach ekonomicznych rzadziej przyciągają naszą uwagę.

Jak można merytorycznie (rzeczowo) argumentować w sprawach moralno-etycznych? W przypadku etyki chodzi przede wszystkim o to, by zmieniać postawy, wykorzystując poszerzoną zasadę kooperacji - solidarność uczuć. Zatem stosuje się argumentację aksjologiczną, odwoływanie do różnych wartości. Dlatego argumentowanie rzeczowe, które by się opierało na faktach, i tak nas zepchnie w aksjologię.

Andrzej Zoll: Problem polega na tym, że obie strony wychodzą z tych samych wartości, tylko nie mogą tego przyznać. Weźmy wczorajszą debatę $\mathrm{w}$ parlamencie dotyczącą ratyfikacji traktatu europejskiego. Przecież to jest typowy przykład - PiS doprowadził do podpisania układu, ale teraz ze względów czysto taktycznych musi ten układ, przez siebie podpisany, zaatakować.

Grażyna Habrajska: Nie sądzę, by wychodzili z tych samych wartości. Jedna i druga strona zgodziła się na podpisanie traktatu, ale oczekują po nim czegoś innego.

Andrzej Zoll: Wobec tego musi się ośmieszyć tych, którzy chcą traktat ratyfikować. Mówi się, że „nie zgodzę się na to, żeby Polska była województwem, nawet samorządowym”.

Grażyna Habrajska: Absolutnie tak, tu się zgadzam z Panem Profesorem, że chodzi o względy taktyczne. Dawno już zauważyliśmy w naszych badaniach nad dyskursem 
publicznym, że uczestnicy tego dyskursu, za pomocą języka kreują nową społeczną rzeczywistość, którą nazwaliśmy trzecią rzeczywistością (obok pierwszej - fizykalnej i drugiej - kulturowej, wyróżnionych przez Michała Fleischera, 2002; por. Awdiejew, 2007). Trzecia rzeczywistość kreowana jest w dyskursie publicznym (przez polityków, dziennikarzy, księży itd.) i polega na tworzeniu nowych lub zmienianiu profilu starych obiektów kulturowych, którym przypisuje się wartości sprzeczne z wcześniej ustalonymi. Na przykład pozytywnie nacechowanemu słowu liberalny nadaje się wartościowanie negatywne przez całkowicie nieuprawnione przeciwstawienie go słowu solidarny itd.

Anna Lubecka: Chciałabym wskazać na jeszcze jedną z dominujących cech dyskursu publicznego, a mianowicie jego urynkowienie, które wynika ze zmian ekonomicznych w kontekście społeczno-kulturowym. W konsekwencji urynkowienia, wartość wypowiadanych słów i tym samym odpowiedzialność za nie, zwłaszcza wtedy, gdy używane są publicznie w formie zmedializowanej, uległy znaczącej zmianie. Informacja stała się towarem, który trzeba sprzedać i to dobrze, co w narastającym szumie informacyjnym i przy wzmożonej konkurencyjności tych, którzy informacji dostarczają - prasy, telewizji, radia i mediów elektronicznych - nie jest łatwe. Stąd informacja ma być przede wszystkim atrakcyjna, co powoduje, że współcześnie informacjami się zarządza, a przez zapożyczenie technik marketingowych (np. shockvertising, enetertising, guerilla marketing) nadaje się im taką formę i treść, żeby zostały zauważone, mogły zaistnieć w przestrzeni publicznej chociaż przez kilka minut. Większość z nich ma więc albo bawić, albo szokować i skandalizować, albo zniesmaczać, pomijając normy etyki i wydawałoby się podstawową zasadę szacunku i empatii dla odbiorcy oraz szacunku dla pewnych uniwersalnych, prymarnych wartości, których nie można ani zrelatywizować, ani tym bardziej zatracić (Cox, 2001; Klein, 2004). Przykładem niech będzie niedawna informacja prasowa o masowych podwyżkach, gdzie pojawiło się sformułowanie tsunami cen uderzy w Polskę. Trudno tę informacje pominąć, ale czy etyczne jest użycie określenia tsunami przywołującego ciągle jeszcze żywe wspomnienie tragedii tysięcy ludzi w tym właśnie kontekście?

Komercjalizacja i urynkowienie dyskursu oraz wynikający z nich etyczny relatywizm nie odnoszą się jedynie do tabloidowych wydań codziennych czasopism czy podobnych w tonie programów telewizyjnych. Wiele znanych osób życia publicznego tak konstruuje swoje wypowiedzi, a używając obecnie popularnej terminologii, zarządza nimi, żeby pomogły im lepiej ,sprzedać” ich publiczny wizerunek, ich tożsamość publiczną. Jedną z zauważalnych form tych działań jest wprowadzenie do niego elementów z życia prywatnego, wybranych 
przez specjalistów od tworzenia wizerunku w zależności od grupy docelowej, do której dyskurs jest skierowany. Dyskurs publiczny ma wielu odbiorców i, podobnie jak w przypadku ekonomicznej segmentacji rynku, także rynek wartości i idei ulega dywersyfikacji, co wpływa na powstawanie odpowiednich gatunków dyskursu publicznego.

Walery Pisarek: Chciałbym podziękować Pani Profesor za wyrażenie urynkowienie słów to bardzo trafne ujęcie tego procesu, któremu podlegają słowa, jak zresztą i wszystko we współczesnej wszechurynkowiającej rzeczywistości. A z argumentacją racjonalną na nasze nieszczęście jest tak, że właśnie ona okazuje się nie bardzo skuteczna w porównaniu z argumentacją, a raczej niby-argumentacją emocjonalną. Wyśmianie, drwiąca uwaga, nawet nie słowo, tylko gest, może zdeprecjonować najbardziej wysublimowane rozumowanie prowadzące do pożądanego i pożytecznego wniosku. Dziękuję, to chciałem dodać.

\section{Prognoza i terapia}

Stanisław Gajda: Często formułuje się sądy orzekające, że Polacy żyją bardziej wczoraj i dziś, zatracając perspektywę bliższej i dalszej przyszłości. Jednak w naszej wiedzy o przeszłości i teraźniejszości - zarówno tej potocznej, jak i bardziej wyrafinowanej - da się dostrzec otwarcie ku przyszłości, pewien horyzont oczekiwań. W tych oczekiwaniach to, co racjonalne, miesza się z odczuciami - nadziejami, obawami, życzeniami i wolą. Zależności między wiedzą o czasie minionym i mijającym a oczekiwaniami stanowią podstawę do tworzenia obrazów tego, co nas czeka. Te obrazy budujemy z przesłanek zawartych w wiedzy o przeszłości oraz korzystając z bogactwa wyobraźni, gdzie znajdziemy potoczne marzenia i wróżby, artystyczne fantazje, ideologiczne utopie, religijne proroctwa, jak i naukowe prognozy.

Z myślenia prognostycznego nie sposób zrezygnować, zwłaszcza przy konstruowaniu programów kształtowania ludzkich wspólnot, zarówno programów orientujących się na realizację wartości wyższych (np. z kanonu kultury ogólnoludzkiej, europejskiej, narodowej) i budowę prawdziwych wspólnot, jak i koncentrujących się na rozwiązywaniu problemów bardziej technokratycznych, jakie powstają przy zarządzaniu ludźmi (zasobami ludzkimi), zbiorowościami. Prognozowanie ma informować o tym, co nas czeka i ostrzegać przed zagrożeniami, kształtować postawy wobec przyszłości, a także umożliwiać podejmowanie trafnych decyzji. 
Wydaje się, że w myśleniu o przyszłości można mówić o trzech stanowiskach: 1. pesymistycznym, czy wręcz katastroficznym, 2. optymistycznym i 3. traktującym przyszłość jako otwarty rachunek. Jak Państwo widzą przyszłość dyskursu publicznego - polską, europejską, globalną?

Diagnozy i prognozy powinny stanowić podstawę do namysłu nad zachowaniami mającymi na celu ingerencję $\mathrm{w}$ rzeczywistość społeczną i do prowadzenia realnych działań sterujących. Jak oceniają Państwo współczesną polską politykę (ang. policy) w zakresie kształtowania dyskursu publicznego (manipulacje, zaniechania itd.)? Jakie powinny nastąpić w niej zmiany (aktorzy, cele, zadania)? Czy w ogóle możliwe są oddziaływania zmierzające do jego naprawy (terapia) i do kształtowania zgodnie z wizją życia społecznego (wychowanie do), czy też jesteśmy skazani na żywiołowe procesy samoorganizacji i ewentualnie zarządzania dyskursem przez niektóre podmioty?

Walery Pisarek: Dziś z całą akademicką powagą roztrząsamy problematykę zarządzania kulturą, jakością, a nawet czasem. Jeszcze dwadzieścia lat temu krytykowaliśmy i ośmieszaliśmy PRL-owskie partyjno-rządowe zapędy do zarządzania prasą, literaturą i w ogóle kulturą. Dziś wyrazy zarządzać, zarządzanie cokolwiek pod amerykańskim wpływem zmieniły znaczenie i zarządzanie językiem, a nawet zarządzanie miłościa stało się w ramach nauki o zarządzaniu akceptowalne.

Marcela Świątkowska: Istnieje powiedzenie, że ma się takiego męża, na jakiego się zasłużyło. Myślę więc, że mamy taki dyskurs publiczny, jaki mamy dyskurs niepubliczny. To przecież nie bierze się znikąd. Kształtuje się bardzo wcześnie, na każdym poziomie edukacji. Chodzi oczywiście o umiejętność posługiwania się językiem i argumentacją. Nie chodzi tylko o wulgaryzację języka, ale zanikanie pewnych wartościujących przymiotników, które są przecież dowodem na to, w jaki sposób oceniamy otaczający nas świat, w najszerszym tego słowa znaczeniu. Przeprowadzony niedawno przeze mnie wśród studentów test wykazał, że funkcjonują $\mathrm{w}$ obiegu $\mathrm{w}$ zasadzie trzy wyrażenia ocenne, które $\mathrm{w}$ dodatku nie są $\mathrm{z}$ natury rzeczy przymiotnikami. Pozwolicie Państwo, że ich tutaj nie przytoczę. Myślę jednak, że jeżeli chcemy podnieść jakość naszego dyskursu publicznego, to trzeba o myśleć o jego zaistnieniu na o wiele wcześniejszym etapie edukacji.

Jerzy Mikułowski Pomorski: Czas leczy rany. Dziś przeżywamy takie zachłyśnięcie się otwarciem na świat polityki, mamy dużo pojawiających się ugrupowań partyjnych, które 
często są efemerydami, ale chcą się wyraźnie zarysować, zaistnieć. Na te próby reagują media, media politycznie zaangażowane, a więc mające swój interes w psuciu jakości dyskursu na tematy publiczne. Proszę zauważyć, że mimo stałego pojawiania się nowych dzienników ogólnokrajowych, żaden $\mathrm{z}$ nich nie zasługuje na markę pisma naprawdę publicznego, czegoś na wzór „Financial Timesa”. Kiedyś miałem nadzieję, że nim będzie „Rzeczpospolita”. Okazało się, że została zepsuta przez politykowanie i z tej szansy zrezygnowała. Kiedyś liczyłem, że pewne dyskusje w telewizji publicznej będą miały charakter prawdziwych dysput politycznych, dysput publicznych. To by było zadanie dla prowadzących, to by ich na pewno nobilitowało, pozwalałoby im dobierać właściwe osoby, ale się zawiodłem. Jesteśmy świadkami pogoni za osobami niewłaściwymi, zapraszania do tego dyskursu publicznego osób, które się zdecydowanie nie nadają, nie potrafią mówić na tematy publicznie ważne. Takie osoby łatwo rozpoznać i dla dobra sprawy nie należy dopuszczać do takich programów. Tymczasem można odnieść wrażenie, że przez dobór uczestników celowo wyklucza się uzyskanie efektu prawdziwej debaty. Komuś zależy, by debata się nie udała. Kiedyś to się zmieni, gdy padną piany i nasza demokracja bardziej się ucywilizuje. Jestem optymistą i sądzę, że to nastąpi, tak jak, odpowiadając na pytanie Pani Profesor, ku memu wielkiemu i miłemu zdziwieniu zniknęło w mowie potocznej słowo zajebiście, a pojawiło się w to miejsce u studentów jedwabiście.

Andrzej Zoll: Chciałbym nawiązać do tego, co powiedziała Pani Profesor Świątkowska. Wychowanie trzeba zacząć bardzo wcześnie. Mamy tu olbrzymie zaniedbania, jeśli chodzi o nauczenie młodzieży dyskutowania, zabierania głosu, spierania się na argumenty. Należę do kuratorium bardzo dużej fundacji niemieckiej "Hertie", która prowadzi w Niemczech w szkołach niemieckich program „Jugend debattiert" (Learning Democracy; http://www.ghst.de/en/index.php). I jest to fantastyczny program. Właściwie we wszystkich szkołach niemieckich prowadzi się zajęcia uczące młodzież publicznej debaty. Powoli zaczyna on wchodzić też i do Polski, do tych szkół, które mają rozszerzony program języka niemieckiego. Młodzież uczy się dyskutować po niemiecku . Chciałbym, żeby nasza młodzież uczyła się debatować po polsku. Wprowadzenie takiego programu uważam za niezwykle ważne. Mogą być różne formy uczestniczenia młodych ludzi w tej debacie. Mieliśmy przykład w ostatnich wyborach - esemesową debatę młodego pokolenia. Ale techniki tu mogą być różne, natomiast potrzeba debaty wśród młodych, i takiej właśnie debaty na argumenty, a nie na różne emocjonalne sformułowania, jest niezmiernie ważna. 
Stanisław Gajda: Na Zachodzie są szkoły twórczego pisania, u nas też próbujemy to przejąć - rzeczywiście przydałaby się szkoła twórczego dyskursu publicznego, twórczego debatowania, po prostu.

A udział Kościoła w dyskursie publicznym dziś i jutro? Proszę bardzo.

Wiesław Przyczyna: Moim zdaniem przed Kościołem otworzyły się nowe możliwości funkcjonowania w sferze publicznej, które w dużej mierze są skutkiem zmian, jakie dokonały się w Polsce po wyborach w 2007 roku. Po pierwsze, wydaje się, że dziś jest mniejsze zagrożenie zinstrumentalizowaniem religii, niż miało to miejsce w latach 2005-2007. Ówczesna władza bowiem usiłowała wykorzystać religię do wzmocnienia instytucji państwa. Dla przykładu można tutaj przytoczyć zaangażowanie Jarosława Kaczyńskiego w przekonanie Benedykta XVI, aby pozostawił stolicę prymasowską w Warszawie. Wyjaśniając to, były premier podkreślał, że „tytuł prymasa jest elementem tradycji i z punktu widzenia państwa nie jest bez znaczenia, gdzie znajduje się stolica prymasów (...). W moim przeświadczeniu Kościół powinien być silny, a temu służy instytucja prymasa" (,Rzeczpospolita” 24.11.2006; http://www.kprm.gov.pl/s.php?id=665).

Po drugie, obecna władza jest niemal całkowicie skoncentrowana na celach skupionych wokół gospodarki (EURO 2012, cud gospodarczy, druga Irlandia), a nie na silnych wartościach. Otwiera to przed Kościołem duże pole do działania, tym bardziej, że Polacy nadal wykazują przywiązanie do katolicyzmu i wartości, które on ze sobą niesie.

I po trzecie, ostatnie wybory pokazały, że Polacy stają się coraz bardziej narodem umiarkowanym, stroniącym od wszelkich skrajności. Wielu z nich źle się czuje, stając przed alternatywą: Radio Maryja z jednej strony, a liberalizm reprezentowany przez byłych księży (Bartosia, Obirka, Węcławskiego) z drugiej.

Marek Zybura: Jakość dyskursu publicznego będzie zależeć nie tylko od technicznych umiejętności prowadzenia go, ale będzie też zależała od wiedzy przedmiotowej jego uczestników. Ze swojego germanistycznego podwórka chciałbym się na ten temat wypowiedzieć w kontekście stosunków polsko-niemieckich. Proszę państwa, dialogowi polsko-niemieckiemu należałoby przywrócić w dyskursie publicznym jego właściwą głębię, jego historycznie głęboki rodowód. Nie trzeba tego w sposób szczególny tłumaczyć tutaj, w Krakowie, choć szeroko w Polsce Kraków w kontekście niemieckim będzie się ludziom kojarzył jedynie z Wandą, co Niemca nie chciała. 
A większość naszych rodaków nie będzie prawdopodobnie wiedziała, że owej Wandzie antyteutoński wstręt dosyć szybko przeminął, jak by to można wnosić z przygód miłosnych, jakich w podwawelskim grodzie doświadczał, a potem w pierwszej księdze swego dzieła z 1502 roku Quattour libri amorum (gdzie, co prawda, Wanda zowie się Halszką) opisał niemiecki, studiujący w Krakowie żak Konrad Celtis. O czym pamięta się równie rzadko, jak i o tym, że Celtis twórczością swoją wywarł istotny wpływ na nowołacińską poezję polską pierwszej połowy XVI wieku, przyczyniając się w ten sposób do rozwoju wczesnego humanizmu w Polsce. Też raczej przeciętny Polak nie będzie w kontekście krakowskim wiedział, że był tutaj taki drukarz niemiecki Jan Haller z Rottenburga, który drukował pierwsze polskie teksty, jak choćby Bogurodzice. Dlaczego? Ano dlatego, że jak pisał w swoich Esejach o sąsiedztwie polsko-niemieckim (1996) Jan Józef Lipski, „nie lubi się u nas pisać i pamiętać o tym, co dłużni jesteśmy cywilizacyjnie i kulturalnie Niemcom".

Z drugiej strony przeciętnym Niemcom nie będzie też raczej znana, aby już pozostać przy tej samej epoce, np. ożywiona niemiecka recepcja pism zaprzyjaźnionego z Filipem Melanchthonem i Matthiasem Flacciusem Andrzeja Frycza Modrzewskiego. Opublikowany w 1557 niemiecki przekład $O$ naprawie Rzeczypospolitej stał się standardowym dziełem politologicznym owego czasu w Niemczech, na które powoływali się uczeni i teologowie tej miary, co Georgius Cassander czy Hieronymus Zanchius. Przy tym sława Modrzewskiego trwała w Niemczech niewzruszenie jeszcze długo po jego śmierci. Podczas wojny trzydziestoletniej dzieła Polaka odgrywały istotną rolę w wysiłkach uczonych (np. Gronoviusa, Grotiusa) podejmowanych dla wypracowania polityczno-prawnych fundamentów przyszłego pokoju. Rozważano nawet wznowienie pod koniec roku 1634 we Frankfurcie nad Menem jego zebranych pism, tak wielkie pokładając nadzieje w sile wymowy proponowanych przez autora zasad współżycia społecznego i religijnopolitycznego.

A przecież przyszłość budujemy w oparciu o przeszłość. Nie będzie zaś dla jej kształtu i perspektyw rozwojowych rzeczą obojętną, do jakich tradycji ze wspólnej przeszłości zechcemy nawiązać: czy do tych, które podsumował w swoich Moraliach (2004 [1688]) bardzo kategorycznie Wacław Potocki (,Jak świat światem nie będzie Niemiec Polakowi bratem”), czy też raczej do tych, o których myślał Modrzewski, czy bliższy nam czasowo XIX-wieczny poeta śląski Max Waldau w swoim wierszu $O$ diese Zeit: „Niemiec podaje Polakowi dłonie / Razem snują plany", w myśl dewizy: quod bonum felixque sit 
populis germanico ac polono. To jeden z najważniejszych wyborów, jakich musimy obecnie dokonać.

Stanisław Gajda: Dziękuję bardzo. Pan Profesor Zybura przypomniał nam o międzykulturowym wymiarze dyskursu publicznego. Panie Profesorze - do Pana Profesora Mikułowskiego zwracam się - perspektywa przyszłości dyskursu europejskiego. Mówi się o tożsamości europejskiej, o jej konstruowaniu, o jej słabościach, ale też o międzykulturowych barierach.

Jerzy Mikułowski Pomorski: To, co powiedziałem o tych polskich eurodeputowanych, jest tak szalenie optymistyczne, że właściwie wypadałoby mi na tym skończyć.

Stanisław Gajda: Ależ to bojowa i zamknięta polska tożsamość narodowa, a ja mówię o życiu w świecie wielokulturowym i o przyszłości Europy/świata.

Jerzy Mikułowski Pomorski: Proszę państwa, my coraz bardziej będziemy Europejczykami, i to będzie nasze doświadczenie kulturowe. Przez pobyty, kontakty będziemy tę europejskość traktować jako pewien obszar, w którym się dość swobodnie poruszamy. Będziemy patrzyli na Europę jako na nasz Dom, który ma szereg pokojów. To nie będą domy narodowe, tylko regionalne. Każdy będzie się czuł dobrze w pewnych pokojach, a być może we wszystkich, to jest w całym domu. Być może te pokoje będą różne dla różnych regionów Polski. Nie powinno nas to martwić. Przecież na wakacje jedziemy zwykle do innego niż nasze miejsca, szukamy wypoczynku w innym pokoju. I czujemy się tam często bardzo szczęśliwi. Wtedy łatwiej będzie prowadzić dyskurs publiczny, bo coraz więcej ludzi będzie się rozumiało, skoro ich doświadczenia będą podobne.

Dyskurs na tematy publiczne, a więc te dotyczące miejsca naszego życia, będzie, mam nadzieję, znacznie bardziej cywilizowany, ale nadal trudny, a nawet trudniejszy, ponieważ doświadczenia tego miejsca będą znacznie bardziej zróżnicowane, niż dziś doświadczenia mieszkańca i turysty z Rynku krakowskiego.

Jerzy Bralczyk: Będziemy teraz coraz bardziej Europejczykami, ale cały czas jesteśmy też Słowianami. Te słowiańskie relacje, powinny być przez nas doskonalone $\mathrm{w}$ dyskursie. Pan Profesor Zybura mówił o potrzebie nowego języka, czy też o rozwijaniu się nowego języka w sprawach niemieckich. Uważam, że dałoby się to odnieść mutatis mutandis do spraw 
rosyjskich. I tu nowy język jest jeszcze bardziej potrzebny. Ponieważ pojawiło się tyle najrozmaitszych resentymentów i różnych uprzedzeń. A to jest akurat i pora, i miejsce, żeby na tym poziomie mówić także o doskonaleniu naszej rozmowy z Rosją.

Marcela Świątkowska: Myślę, że są mechanizmy w takim dyskursie międzykulturowym, które można wykorzystać. My się najczęściej obrażamy, gdy gdzieś pojawia się jakiś nieprzychylny nasz obraz. Często żądamy też przeprosin. Nie mamy w tej chwili najlepszej prasy w różnych krajach europejskich. Są jednak strategie dyskursywne, które możemy wygrać. Bardzo pozytywnym przykładem jest polski hydraulik we Francji. Polak kojarzy się tam przede wszystkim ze znanym od czasów napoleońskich powiedzeniem pijany jak Polak. Słynny polski hydraulik pojawił się w momencie zagrożenia rynku pracy we Francji najazdem nielegalnych polskich robotników. Na francuskie niechęci Polska zareagowała zadziwiająco, jak na nasze umiejętności i tradycje - tym słynnym afiszem zapraszającym do nas. Ten zabieg PR zrobił niesłychaną karierę i stereotyp pijanego Polaka ma szansę zostać zastąpiony przez obraz przystojnego hydraulika. Jest to pewna droga przełamywania stereotypu poprzez medialną, a nawet multimedialną reakcje pozytywną, trafiająca do szerokiej publiczności.

Władysław Chłopicki: Z dużym zainteresowaniem słuchałem tej dyskusji i zastanawiałem się, w którym momencie padnie termin czy pojęcie amerykanizacji dyskursu publicznego. Myślę, że tego mi trochę tutaj zabrakło, dlatego chciałbym parę słów na ten temat powiedzieć w kontekście „europejskości”, o której Państwo wspomnieli. Co oznacza amerykanizacja dyskursu publicznego? Chodzi o pewne spłycenie dyskursu, czyli poruszanie się jakby po powierzchni problemów, odrzucenie głębi i skomplikowania, w których uczestnicy dyskursu nie widzą szansy na lepsze zrozumienie rzeczywistości, a jedynie niepotrzebne zamazanie odpowiadającego im uproszczonego, czarno-białego obrazu świata. O tym zjawisku była już mowa kilkakrotnie w naszej dyskusji.

Nie było natomiast wprost mowy o tym, co to spłycenie za sobą niesie. Otóż potrzebna w dyskursie publicznym staje się pewna błyskotliwość i humor, które w jakimś stopniu zastępują głębię, stają się jej substytutem. A więc żartobliwy dyskurs staje się przeciwieństwem tradycyjnej powagi, cechującej polski dyskurs publiczny. Żartowanie w sytuacji publicznej uważane było w Polsce - tak mi się przynajmniej wydaje - za coś niestosownego. Dlatego to, co Pan Profesor Bralczyk powiedział o kpiarzach-felietonistach, jako uczestnikach dyskursu, wydaje mi się niepełne. Z anglosaskiego punktu widzenia, bo dla 
Brytyjczyków żartobliwość dyskursu też jest ważna, humor stanowi nieodłączną właściwość dyskursu publicznego. Jeżeli go nie ma, jeżeli nie zaczyna się, nie przerywa i nie kończy wypowiedzi, czy jakiegokolwiek wystąpienia publicznego, żartem - takim czy innym, zależnie od sytuacji i typu wypowiedzi, a może to nawet być kazanie w kościele - to coś nie do końca jest z tym wystąpieniem w porządku. Jeśli mówimy tu o przyszłości dyskursu, to mówimy, jak sądzę, także o amerykanizacji w sensie odejścia od tradycyjnej powagi dyskursu publicznego i przejścia do trochę innego modelu dyskursu. Pan Profesor Mikułowski wspomniał o tym z nieco innej perspektywy - przychodzi młode pokolenie, które inaczej już postrzega świat, ma bardziej egalitarny stosunek do dyskursu i do jego uczestników. W związku z czym ich dyskurs będzie prawdopodobnie zmieniał się w takim kierunku. Ten proces najwyraźniej już się rozpoczął.

Żeby zilustrować tę tezę, chciałem podać przykład niezmiernie ostatnio popularnej reklamy pewnego banku, w której występuje znany angielski komik John Cleese. W udawanym dialogu z producentem reklamy Cleese próbuje go przekonać (po angielsku), że on sam ma prawo do otrzymania bardzo pożądanej pożyczki z tego banku, mimo że nie jest Polakiem. Koronnym argumentem jest to, że jego ciotka pochodzi z Pcimia. W kontekście amerykanizacji dyskursu publicznego, bardzo symptomatyczna była reakcja władz tej podkrakowskiej miejscowości. W pierwszym odruchu wójt postanowił podać bank do sądu za obrazę Pcimia i jego mieszkańców. Pod wpływem zdroworozsądkowych argumentów, zapewne pochodzących od jego młodych i już nieco zamerykanizowanych doradców czy mieszkańców Pcimia, postanowił jednak wykorzystać tę darmową reklamę i przy wjeździe do Pcimia niebawem mają pojawić się wielkie napisy: Miasto rodzinne ciotki Johna Cleese'a. Władze Pcimia zamierzają także zorganizować doroczną imprezę w amerykańskim stylu pod hasłem: „Tydzień Poszukiwań Ciotki.” Jeśli te plany zostaną wprowadzone w życie, to znaczy jeśli powaga dyskursu publicznego nie zwycięży, będzie to dowód na to, że jednak „idzie nowe” i że humor jakoś stymuluje dyskurs publiczny.

Nie wiem, czy to byłby wniosek optymistyczny czy pesymistyczny. Pan Profesor Pomorski wyraził tu pogląd, że zmiany następują w kierunku ogólnie pozytywnym. Ja mam mieszane uczucia. Amerykanizacja nie zwiastuje chyba niczego obiecującego, natomiast brytyzacja dyskursu publicznego, także w sensie akceptacji dla postaw autoironicznych, mogłaby trafić na bardziej podatny grunt.

Anna Lubecka: Jednym z wyzwań dyskursu publicznego w Polsce jest uczestnictwo w nim coraz większej liczby obywateli. I w tym kontekście budowania publicznego dyskursu 
obywatelskiego należałoby również powiedzieć o dyplomacji publicznej, czasem także nazywanej obywatelską. Oznacza ona działania osób prywatnych, czasem nawet nie mających świadomości występowania w tej roli na rzecz spraw publicznych. Ta nieoficjalna forma lobbingu w imię wartości społecznie pożądanych jest już niezwykle popularna i formalnie uznana za ważne działania przez rządy wielu państw, które w dyplomatach publicznych widzą współtwórców rzeczywistości społecznej.

Podobnym wyzwaniem, może nawet trudniejszym, gdyż nasyconym wieloma emocjami i właściwie bez wzorca dobrej praktyki, jak go prowadzić, jest dyskurs publiczny pomiędzy nowymi i starymi mniejszościami oraz mniejszościami i większością. Demokratyzacja społeczeństwa spowodowała wyjście z marginesu wielu tzw. milczących mniejszości, które de jure mają zagwarantowane wszystkie prawa, również prawo do pełnego uczestnictwa $\mathrm{w}$ dyskursie publicznym, ale de facto uczestniczą $\mathrm{w}$ nim $\mathrm{w}$ bardzo niewielkim stopniu. Ich nieobecność w przestrzeni i w dyskursie publicznym przez wiele lat ani nie nauczyła ich samych ani większości, jakiego języka używać. Najczęściej jest to mowa nienawiści, pełna złych emocji, eskalacji wzajemnych żądań i roszczeniowej postawy wobec siebie. Tradycja polskiej tolerancji dla inności nie znajduje potwierdzenia we współczesnych czasach. W dużej mierze odpowiedzialne za taki stan rzeczy są media, na przykład zamykając te mniejszości w umacniających uprzedzenia stereotypach. Osoby niepełnosprawne, szczególnie artyści niepełnosprawni, właściwie ciągle nie mają możliwości zaistnienia w przestrzeni społecznej na tych samych warunkach, co osoby pełnosprawne. Dużą winę ponosi także moda na wielokulturowość, która powoduje bardzo powierzchowne traktowanie pluralizmu kulturowego. Dodatkowo wypaczona idea politycznej poprawności i dyskryminacji pozytywnej skutkują postawami wrogości wobec grup społecznie defaworyzowanych, uniemożliwiając dialog w imię wspólnych interesów.

Dołączając do głosów Państwa Profesorów o przyszłości polskiego dyskursu w szerszym kontekście na forum międzynarodowym, myślę, że nie można nie zastanowić się nad wpływem na dyskurs procesu rekonstrukcji polskiej tożsamości. Polska tożsamość jeszcze się nie wykrystalizowała co najmniej z dwóch powodów. Po pierwsze, żyjemy w baumanowskiej płynnej rzeczywistości postmodernizmu, gdzie brak jednoznacznych i stałych wzorców tożsamościowych i każdy musi sam podejmować trud tworzenia siebie (por. Bauman, 2000). Po drugie, nasza najnowsza historia i przemiany transformacyjne, wejście w procesy globalizacyjne, przede wszystkim w sferze wartości, pozostawiły nas w pewnym chaosie aksjologicznym. Nasza rzeczywistość jest ciągłą konfrontacją naszych polskich tożsamości z tożsamościami globalnymi, chociażby w kwestii pamięci historycznej, o czym 
mówił Pan Profesor Zybura. I stąd pytając o to, kim jesteśmy, ciągle mamy wiele pytań i chyba więcej znaków zapytania niż jasnych, wyraźnych, jednoznacznych odpowiedzi.

Wchodząc w 1989 roku do Europy w nowej roli także jej architektów, nie zawsze znamy scenariusze, jak $\mathrm{w}$ tej nowej roli wystąpić. Potrzeba nam pewnego czasu i doświadczenia, aby stać się Europejczykami nie tylko de nomine. Jeżeli zdobędziemy zaufanie do samych siebie, zdobędziemy także samoświadomość i jednocześnie poczujemy się pewni, poczujemy, że jesteśmy coraz bardziej Europejczykami. Nasza europejskość, która stanie się oczywistością - nie za rok, nie za dwa, ale w następnych pokoleniach, pozwoli nam także z innej perspektywy patrzeć na to wszystko, co się dzieje w Europie. Inaczej zrozumiemy w niej naszą rolę jako jej aktywnych partnerów, którzy mają pełne prawo do tego, żeby broniąc własnego publicznego interesu, jednocześnie identyfikować ten interes z szerszym interesem europejskim. Jest to chyba problem w ogóle wszystkich nowych demokracji, społeczeństw, które wchodzą obciążone pewnym doświadczeniem postkolonializmu. Termin ten też stosuje się do naszego doświadczenia polskiego, do Europy Centralnej i do Europy Wschodniej, a jego wpływ widoczny jest w dekonstrukcji wcześniej obowiązującego modelu dyskursu publicznego i jego konstrukcji w oparciu o standardy demokratyczne, o czym wyraźnie mówił Pan Profesor Mikułowski.

I jeszcze jeden wątek ściśle związany z niedookreślonością polskiej tożsamości, znajdującej się w ciągłym statu nascendi. Był on już wcześniej podjęty przez Panią Profesor Świątkowską, która mówiła, że Zachód odbiera nas albo jako bardzo agresywnych, kłótliwych, bez poczucia humoru w stosunku do siebie samych, którzy starają się forsować swoje argumenty, bronić siebie, albo jako zbyt łatwo poddających się. Są to typowe zachowania, kiedy nie czujemy się pewnie. Wtedy albo uciekamy, albo zwalczamy oponenta. Wyzwaniem dla nas jest, aby zamiast tego zwalczania lub uciekania publicznie podjąć dialog i traktować go jako ramy do dyskursu publicznego.

Grażyna Sawicka: Chciałabym nawiązać do sformułowania Pana Profesora Mikułowskiego, który powiedział, że młodzi są otwarci. Ja muszę powiedzieć, że śledzę często fora internetowe, na których młodzi - bo tam na pewno są w większości młodzi - wypowiadają się, oczywiście anonimowo, na temat bieżących wydarzeń. W tych forach jest przede wszystkim bardzo dużo agresji. I właściwie ta młodzież, moim zdaniem, nie jest zorientowana, o czym mówi. Wypowiedzi mają najczęściej charakter emocjonalny, czasem tylko zdarza się refleksja albo komentarz związany z tematem dyskusji. 
Jerzy Mikułowski Pomorski: A skąd Pani wie, że to są młodzi?

Grażyna Sawicka: Oczywiście, nie wiem. Może raczej wnioskuję, po sposobie wypowiadania się, ponieważ jestem językoznawcą. Myślę więc, że mogę tutaj z dużym prawdopodobieństwem powiedzieć, iż większość uczestników tych forów są to młodzi ludzie. I powtarzam, że bardzo często nie da się zauważyć za ich wypowiedziami jakiejś wiedzy i świadomości tego, o czym ci młodzi ludzie mówią. Chcę natomiast powiedzieć o pewnym forum, które znalazłam przez przypadek. Forum to trwało ledwie kilka dni i jest już zamknięte, gdyż zostało utworzone w związku z pewnym wydarzeniem politycznym, jakim było odejście premiera Kaczyńskiego. Wydarzenie to zbiegło się, jak pamiętamy, z powołaniem nowego rządu, z sytuacją, kiedy pan prezydent Lech Kaczyński był zagniewany, obrażony. Wówczas jacyś ludzie założyli forum, składające się jakby z dwóch odrębnych (jednak komplementarnych) subforów: „Przeproś prezydenta” i drugie - „Żegnamy premiera”. Łącznie w obu zawarto ponad siedem tysięcy komentarzy. I muszę powiedzieć, że lektura ogromnego materiału językowego z tego forum była dla mnie bardzo pouczająca. Uczestnicy w większości „przepraszali” posługując się np. ironią (przepraszam, choć nie wiem za co; przepraszam Pana Panie Prezydencie za to, że popieram inna partie niż Pan i że ta partia wygrała wybory), rozpaczliwym komentarzem (przepraszam, ie musiatem wyemigrować do Irlandii), żartem (uśmiechnij się i nie gniewaj się, proszę), aluzją literacką (śpieszę się przepraszać, bo tak szybko znikaja). Rzeczywiście na tym forum odbywała się bardzo rzeczowa, sensowna dyskusja i ujawniały się nowe sposoby myślenia i interpretowania bieżących wówczas wydarzeń politycznych, dowodząc dużej wrażliwości młodych ludzi na materię dziejącej się na ich oczach historii.

\section{Źródło}

Dyskusja miała miejsce w czasie V konferencji Tertium w dniu 13.03.2008. Po raz pierwszy została opublikowana w roku 2008 w tomie Język a komunikacja 23 pod redakcją Władysława Chłopickiego i Stanisława Gajdy. 